\title{
How Land Use, Climate Change, and an Ageing Demographic Intersect to Create New Vulnerabilities in Hong Kong
}

\author{
Wing Shan Kan ${ }^{1}$ and Raul P. Lejano ${ }^{2, *(D)}$ \\ 1 Felizberta Lo Padilla Tong School of Social Sciences, Caritas Institute of Higher Education, \\ Hong Kong SAR 999077, China; wskan@cihe.edu.hk \\ 2 School of Culture, Education, and Human Development, New York University, New York, NY 10003, USA \\ * Correspondence: lejano@nyu.edu; Tel.: +1-949-8128150
}

check for updates

Citation: Kan, W.S.; Lejano, R.P. How Land Use, Climate Change, and an Ageing Demographic Intersect to Create New Vulnerabilities in Hong Kong. Land 2021, 10, 391. https:// doi.org/10.3390/land10040391

Academic Editors: Michael Keith, Chenghe Guan and Jialin Liu

Received: 17 March 2021

Accepted: 6 April 2021

Published: 9 April 2021

Publisher's Note: MDPI stays neutral with regard to jurisdictional claims in published maps and institutional affiliations.

Copyright: (c) 2021 by the authors. Licensee MDPI, Basel, Switzerland. This article is an open access article distributed under the terms and conditions of the Creative Commons Attribution (CC BY) license (https:// creativecommons.org/licenses/by/ $4.0 /)$.

\begin{abstract}
As extreme weather events seemingly increase in frequency and magnitude, we are accumulating evidence about how the intersection of circumstances creates vulnerability. The specter of elderly residents in Brooklyn, New York, trapped in their apartments for days due to flooding from the storm surge brought by Hurricane Sandy, provides us a troubling lesson. As vulnerability emerges from the confluence of multiple factors, changing social, natural, and other factors combine to create unimagined problems. Hong Kong is a case in point. The city has seen much of its new development occurring on reclaimed coastal land. At the same time, there has been a significant demographic shift as the city's elderly population has been its fastest growing demographic. The social transition also means more elderly persons living alone. All of these produce conditions that render the population increasingly vulnerable to coastal flooding. Yet, there is not enough systematic effort, in major cities, at identifying these vulnerabilities. Hong Kong is emblematic of coastal cities the world over, in that it has yet to come to a full realization of such emerging risks. Future research must be able to analyze intersectionalities.
\end{abstract}

Keywords: vulnerability; extreme weather; climate change; resilience; ageing

\section{Introduction}

On 29 October 2012, Hurricane Sandy swept through the east coast of the United States. By the time it arrived at metropolitan areas like New York City, its winds had subsided to less-than-hurricane levels, and yet, post-event assessments would recognize it as one of the most devastating storms in the nation's history. Hurricane Sandy illustrates the key point of this article, which is how vulnerability emerges from a (sometimes unanticipated) confluence of events and conditions.

Among the neighborhoods most beleaguered by Hurricane Sandy was the Red Hook district of Brooklyn, New York. A strong storm surge swept up its streets, which had become channels for river-like flows of water. Located at the confluence of the East and Hudson Rivers, Red Hook saw storm surges estimated at around six feet above ground level. In the Red Hook Houses, apartment buildings run by the city housing authority, elderly residents were trapped for days, some of them alone, running low on water, food, and medication.

The story of Red Hook is a lesson in understanding what causes vulnerability: the intersection of multiple factors involving natural hazards, socioeconomic conditions, built form, and other factors. It gives us clues for analyzing hotspots of vulnerability and helps us understand why these are so often missed. There are two key ideas that we will discuss in this article. We will mainly take up the specific hazards described above, which is that of massive storm surges due to tropical cyclones which can engulf coastal cities, but the lessons we learn apply to other catastrophic events.

There are many reasons that communities, and authorities, are often caught unprepared for these kinds of events, but two stand out. 
(1) Imagining the Extreme

One thing the disaster literature has brought to light is that, very often, hazards like a large storm surge are events that the stricken communities had never seen or experienced before. The residents and officials of New York City had never imagined (or experienced) that its streets would become waterways and that Battery Park would become a large lake with, at one point, more than 10 feet of water. We know that tropical cyclones will cause large storm surges somewhere in the world each year, but which town actually gets hit is hard to predict. As another example, the massive storm surge caused by Supertyphoon Haiyan, which was predicted days in advance, still caught both residents and the authorities of the Philippines by surprise, and thousands perished [1].

(2) Intersectionality

The other elusive thing about pinpointing vulnerability is that, often, it emerges from the confluence of elements, no single one of them being decisive. Modelers are getting better at predicting which coastal areas are most prone to storm surge. One can easily map this one-dimensional understanding of vulnerability. However, what if it is the intersection of factors that include the social, the built, the economic, as well as natural? Mapping these hotspots is not even the hardest part-what is, is understanding the complex processes that create these intersectionalities. In Red Hook, the social element amounted to many marginalized, lower-income, elderly residents living alone or with other elderly companions in areas isolated from the main. Marginalization includes racial discrimination, economic exclusion, as well as physical isolation (e.g., lack of available transportation). The built element consisted of poorly equipped public housing apartment buildings near the water's edge.

The term, risk, is most often associated with the probability that an extreme event will cause adverse outcomes in a community. Risk is increased by the degree of vulnerability of the community and mitigated by adaptive measures taken by the same. This necessitates some discussion of what vulnerability means.

What is most elusive is that no one conventional measure of vulnerability may stand out but, instead, vulnerability may emerge from the confluence of a number of elements coming together, creating vulnerability through their combined effect (e.g., [2]).

The concept of vulnerability (to natural hazards) traces much of its lineage to longstanding research on the geography of natural hazards. Cutter describes it in these terms: "Vulnerability is the likelihood that an individual or group will be exposed to and adversely affected by a hazard. It is the interaction of the hazards of place (risk and mitigation) with the social profile of communities" [3]. Timmerman described it as "the degree to which a system acts adversely to the occurrence of a hazardous event... conditioned by a system's resilience (a measure of the system's capacity to absorb and recover from the event)" [4]. Researchers almost universally recognize how the risk of an adverse outcome, due to a natural hazard, for a community is a complex function of human and natural factors. The Intergovernmental Panel on Climate Change (IPCC) describes vulnerability as the susceptibility of a population that is exposed to a hazard to experience adverse outcomes [5]. Long and Rice discuss how these adverse outcomes are mediated/mitigated by the capacity of a community for adaptation, which can reduce exposure and/or susceptibility [6].

The related concept of resilience was defined by Walker as "the capacity of a system to absorb disturbance and reorganize while undergoing change" [7], which may require, as Folke et al. [8] pointed out, adaptation and transformation of the system to withstand such disturbance. These desired properties of the system act to reduce the vulnerability of the population (and, in general, the socioecological system of a place) to disturbances like extreme weather. Adaptation will require communities and authorities to increasingly imagine and respond to new, emergent conditions that increase vulnerability [9].

As Cutter et al. [10] describe it, the vulnerability of place (and community) emerges through a complex interaction between social factors and geophysical. As complex socialecological systems, phenomena such as vulnerability and resilience exhibit nonlinearity and inherent uncertainties, or a capacity for unexpected responses [11]. Envisioning different 
scenarios can be a planning strategy $[12,13]$, as some scholars have combined scenario planning and composite vulnerability mapping to deal with the inherent complexity $[14,15]$. In this article, we propose that using stories from events experienced elsewhere, such as the Red Hook narrative, can help communities imagine such scenarios. Logically, these exercises can be used to build adaptive capacities in local social networks and identify measures to increase resilience in the multiple components of interdependent systems [16]. Scenarios, however, cannot be limited to predictable situations, since complex systems exhibit unpredictability and indeterminacy-somehow, planners need to imagine possibilities belonging to the "unknown unknowns" [17]. With complexity, we need to imagine what is possible, not just what is probable [18].

In this paper, we do not redefine vulnerability so much as to interpret it in specific ways-i.e., how susceptibility increases from changing demographics, urban development patterns, and changing climatic patterns. We have also found that our understanding of the intersection of multiple patterns and processes that constitutes vulnerability is aided by a sociological interpretation as well-namely, Bourdieu's notion of multiple forms of capital [19]. In this case, we can view vulnerable places (and communities) as having deficits in different forms of capital [20]. This includes physical capital, such as seawalls, and natural capital, such as the loss of coastal open space that served as buffer zones. This also includes deficits in social capital, which can be the case when significant numbers of residents live in isolation and lack support during a tropical cyclone. We will illustrate how changing conditions can create new forms of vulnerability in Hong Kong.

In the following, we briefly discuss some of the factors that intersect to create hotspots of vulnerability.

\subsection{Natural: Climate and Extreme Weather}

The unimagined character of extreme weather is exacerbated by the fact that we are getting increasing scientific evidence that both the frequency and magnitude of tropical cyclones may be increasing with climate change. While the science is still unfolding, there is already confidence in predicting such increased intensities for the North Atlantic and Pacific Oceans [21,22]. This adds to the element of surprise-i.e., areas witnessing an event no one had ever experienced before. Worst of all, it is entirely possible that some areas will see extreme events beyond anything in their recorded history-so-called "grey swan" events [23]. Moreover, previous experience with extreme weather does not necessarily prime people to better understand the risk of future climate change. While personal experience can create an affective route to greater concern for changes in weather and climate, more explicit cognitive linkages between the two are needed for people to causally attribute weather extremes to climate change [24,25]. Furthermore, using recent history (i.e., within one's lifetime) of weather events to gauge the probabilities of future extreme events is prone to underestimate such probabilities in the light of climate change [26].

\subsection{Built: Land Use Development}

Pressures on urban land development can concentrate dense residential areas near the coast, filling in what used to be green spaces in a city [27]. The higher the densities, the more people put in harm's way, the more transportation corridors can get snarled with traffic, the larger the need for emergency supplies, etc. Densification can create urban "channels" where water can rush through. In many cities, these spaces can include large tracts of reclaimed land, created by infill, that are flat and close to sea level. Much of New York City's coastal areas are such, and Hurricane Sandy covered up much of this reclaimed land.

We should note that, even when urban planners are cognizant of vulnerabilities, part of the problem lies in path dependency-i.e., the extent to which built form is a product of historical decisions, some of which accorded low priority to hazards, environmental factors, and other externalities. For example, the Red Hook Houses were located near the waterfront because these were originally intended for shipyard laborers working at the docks, and 
natural barriers and buffer areas were replaced by waterfront development [28]. Moreover, planners may be less willing or capable of considering the uncertain, probabilistic nature of risk (from storm surge and other extreme events) in their planning, creating a "a danger that investment in disaster preparedness and mitigation will be left outside of urban development strategy" [29].

\subsection{Social: Demographic Transition}

There are also demographic shifts underway. In many countries, the population pyramid is getting more "top heavy", and the elderly constitute increasing proportions of the population. This is not to depict older persons as lacking in agency or ability, but to remind ourselves that, among this group, are many who may be frail and isolated. At the same time, the lack of social security and economic marginalization for poor and middle class in many parts of the world means that many people do not have the resources to manage and recover from disastrous events. Urbanization also means high rents, inadequate living spaces, and dispersion of extended families, leaving many of the vulnerable living alone.

\section{Case Study: Hong Kong}

Hong Kong is a case in point. It is a high density metropolis where, because much of the inland area is steeply sloped, high rise buildings are crowded along the nearshore area. It lies in the region of the South China Sea and western North Pacific, which receives an average of 15 typhoons a year, though a "direct hit" of a tropical cyclone on the city only occurs around once every 5 years (Defined by the Hong Kong Observatory as a typhoon with hourly mean winds of $118 \mathrm{~km} / \mathrm{h}$ or higher, with the eye passing within $100 \mathrm{~km}$ of Hong Kong (https:/ / www.hko.gov.hk/en/informtc/historical_tc/histtype.htm, accessed on 1 March 2021). Still, there have been a number of devastating events. Perhaps the worst was the Great Hong Kong Typhoon of 1937, which created a record storm surge and resulted in 11,000 fatalities [30]. However, this event has receded from personal and institutional memory.

The point is that it is the confluence of different factors that gives rise to new vulnerabilities. Hong Kong's infrastructure, including its drainage system, surpasses most cities in the world (New York City, on the other hand, moved to update its stormwater management code in the wake of Hurricane Sandy (https:/ / www1.nyc.gov / site/dep/water/ unified-stormwater-rule.page, accessed on 1 March 2021). However, it is the overlapping of multiple factors that create vulnerability and that, perhaps, hazard experts can miss until disasters reveal them (as in Red Hook).

The factors that were implicated in Red Hook are also found in Hong Kong, but perhaps in even more magnified form. The pressures of urbanization in Hong Kong are like nowhere else, and indices of housing affordability consistently rank Hong Kong as the least affordable city in the world [31]. This creates high-rise residential tower blocks that are like islands of isolation where, should there be a power outage, would trap elderly and frail residents in upper stories. Hong Kong property, the most highly priced real estate in the world, is scarce, creating large incentives to reclaim land, such that today, about $27 \%$ of the city's population lives on reclaimed land (Sustainable Lantau Office. https:/ / www.lantau.gov.hk/en/faq/index.html, accessed on 1 March 2021).

The demographic shifts discussed above are taking place in Hong Kong, as well, but in magnified form. There is a rising elderly population in Hong Kong due to the increase in life expectancy and a decline in the birth rate. The number of elderly persons aged 65 and above is predicted to rise from $18.4 \%$ (1.32 million) of the total Hong Kong population in 2019 to $33.3 \%$ in 2039, which will be around 2.52 million seniors [32]. Hong Kong has the highest life expectancy in the world: 88.2 years for women and 82.4 years for men (United Nations Population Division. https://www.worldometers.info/demographics/life-expectancy/, accessed on 1 March 2021).

Older people are often considered to include the most disempowered and vulnerable persons in society because a number in this age group typically experience poor health, 
poverty, under-education, especially for those who are living alone without family support. Family support is kind of social capital which can empower older people to overcome life challenges and enhance their well-being [33]. However, due to the changing socioeconomic environment, the nuclear family and single household have become the majority household structures in Hong Kong. More young people live apart from their parents after marriage, and elderly couples or individuals are increasingly living on their own. Of 261,421 elderlyonly households in 2016, more than half of that (58.3\%) were older persons living alone. In 2016, there were 152,536 elderly aged 65 and above that were living alone which increased by $54.3 \%$ from 98,826 in 2006 [34].

Therefore, what we see in Hong Kong is not any one factor that stands out, but the intersection of natural, built, and social factors that, together, constitute vulnerability.

The district of Tai Po is an example of this (see Figure 1). Much of the Tai Po Center area was built on reclaimed land and relatively flat. As seen in the Figure, it lies in a bowl-shaped bay which can be conducive to storm surge if the wind blows from the east. In 2018, the storm surge from Typhoon Mangkhut recorded a water level of $4.71 \mathrm{~m}$ above chart datum at Tai Po Kau [35]. Yet, it was not included among government listed storm surge hotspots (Hong Kong Drainage Services Department: https://www.dsd.gov.hk/uploads/page/ CoreBusiness/flood_prevention/Our_Flooding_Situation/dld4014_storm_surge_spots.pdf, accessed on 1 March 2021).

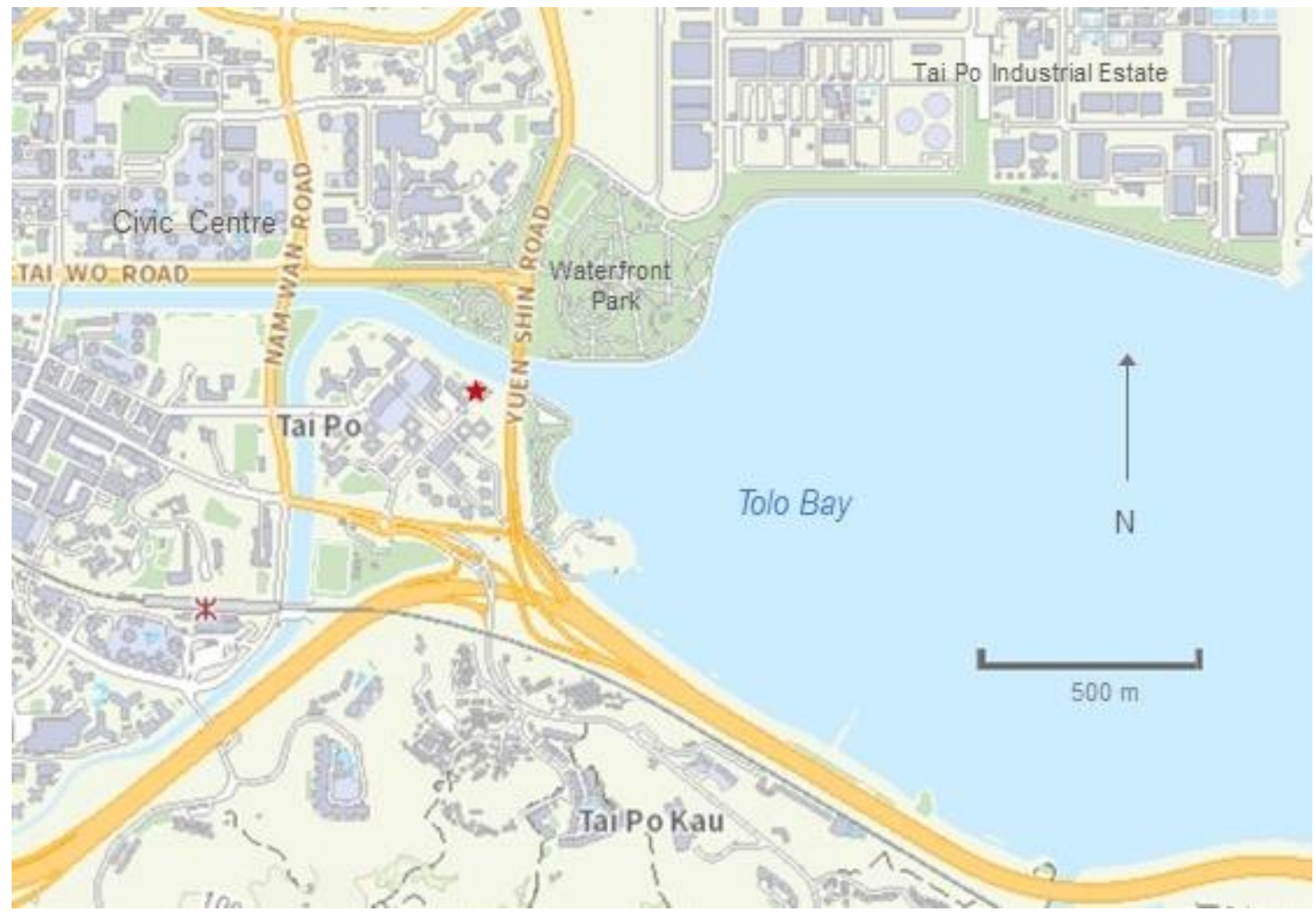

Figure 1. Map of Tai Po, Hong Kong (coastal area off Tolo Bay). (Source of basemap: Hong Kong Lands Department, GeoInfo Map https:/ / www.map.gov.hk/gm, accessed on 1 March 2021).

The area shown in Figure 1, which encompasses the Tai Po Town Center, has a greater concentration of elderly residents (17.8\% compared to $15.2 \%$ in the rest of the district). Additionally, there will be many elderly residents in apartment buildings within half a kilometer from the water. Again, this is not to typify older persons as being less than capable of managing; but, within this category, one will find a proportion who are more frail and isolated. 
In Tai Po, we find residential towers located close to the coast. One such apartment building is shown in Figure 2 (its location indicated by the symbol in Figure 1). In other words, Tai Po may be replicating the conditions in Red Hook, and perhaps as intensely so.

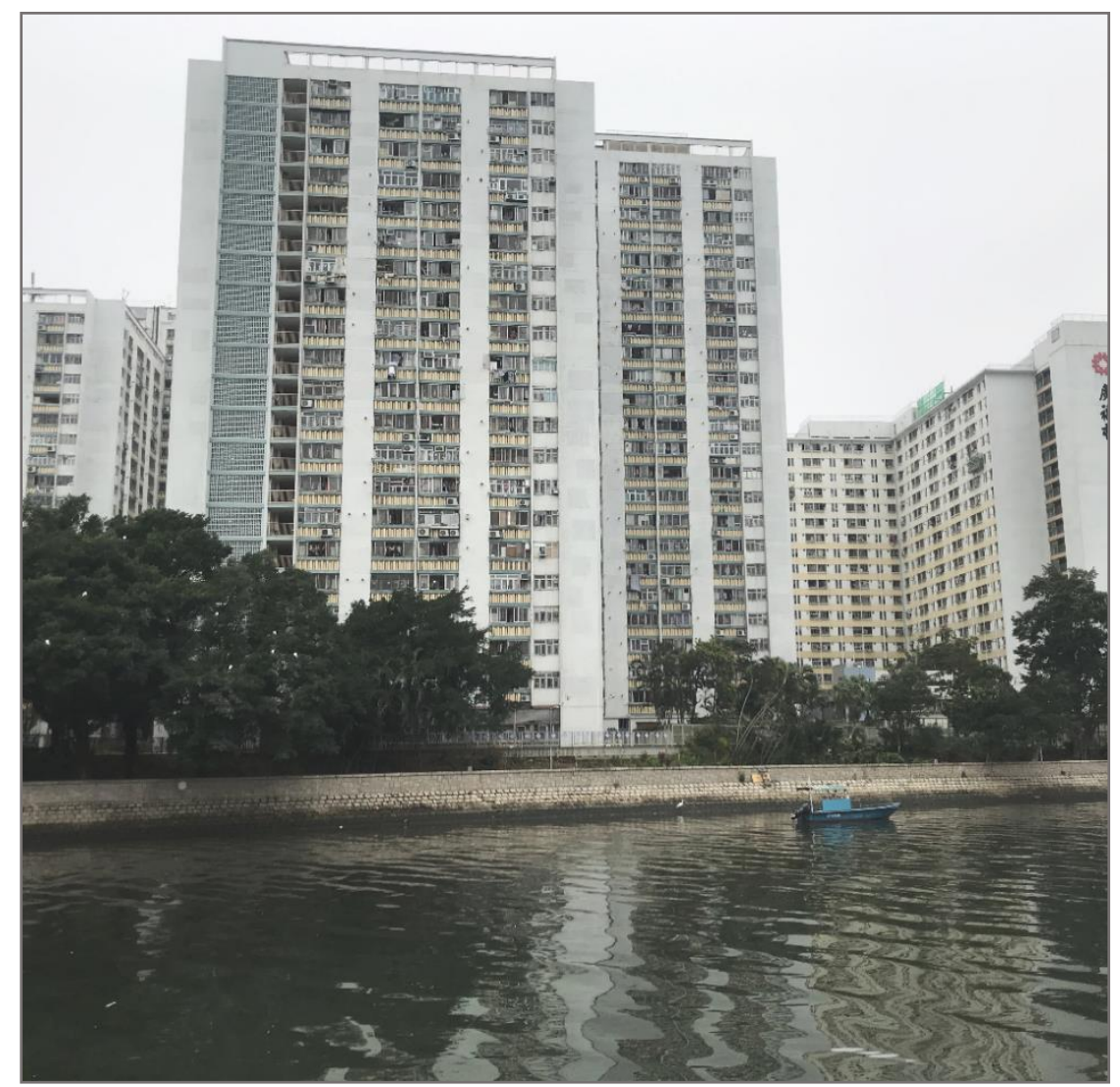

Figure 2. Apartment Building in Tai Po. (Source: authors).

Most residents of Tai Po will not remember the last time its streets were flooded by a typhoon. Additionally, almost no one will remember the Great Hong Kong Typhoon of 1937, when it is said that a $9 \mathrm{~m}$ wave struck Tai Po, killing thousands (http:/ / www. hurricanescience.org/history/storms/1930s/HongKong/, accessed on 1 March 2021). Such events have become unimaginable, which can prime an area for calamity.

\section{Conclusions}

In this article, we highlight two important reasons that extreme events, such as tropical cyclones, turn into disasters. One is the unpreparedness that arises from our basic inability to imagine the hitherto unimaginable. Additionally, what makes these events unimaginable can stem from the fact that people may have never experienced this before.

Perhaps what is needed is for analysts, and societies, to become more skilled at imagining. One way to go about this might be to collectively posit different complex scenarios of how the system might fail. Failure analysis is often done for engineered systems, but most often, such analyses consider the intersection of natural and engineered factors, but not the social, economic, and other dimensions. What is required is the kind of imagination that looks for complex pathways by which all these elements intersect, sometimes in ways that we have never seen before.

It will also help to construct language that captures the unimaginable in everyday narratives that people can tell each other [36]. Knowledge of hazards are often couched in the technical, which portrays this knowledge as being out of reach of communities. However, this is part of the problem, as society tries to engineer away the relationship between people and their environment. 
Analysis has to be able to imagine and study complex processes that make people, such as in Red Hook, vulnerable. To date, much of the vulnerability research (which began in the field of geography) has involved mapping indices (including socioeconomic factors) on digital maps. However, there is a lot about vulnerability that does not show up on a map (at least, not two-dimensional ones) and involve studying processes on site. How would frail or disabled residents manage evacuation? What resources are available to search for and assist trapped residents when systems are down? What scenarios are planners and disaster risk reduction specialists not yet able to imagine?

Additionally, how do we empower residents to reduce their risks and accommodate the unexpected? Rather than assume that the public, including the older population, are helpless, we need to regard residents as not just targets of intervention but active agents of it. A relational approach to risk communication means residents themselves can help identify, manage, and communicate the knowledge of vulnerability [37]. All stakeholders should be engaged in the coproduction of knowledge around vulnerabilities to extreme weather [7]. In addition, what new resources could be brought in to increase resilience? Such measures would include built and natural assets such as urban green space [38]. They would also involve new processes such as new social networks that ensure everyone in the city is connected, and no one is an island [39]. The essential task involves collective imagination.

Author Contributions: Conceptualization, W.S.K. and R.P.L.; methodology, W.S.K. and R.P.L.; investigation, W.S.K. and R.P.L.; writing-original draft preparation, W.S.K. and R.P.L.; writing-review and editing, W.S.K. and R.P.L. Both authors have read and agreed to the published version of the manuscript.

Funding: This research received no external funding.

Institutional Review Board Statement: Not applicable.

Informed Consent Statement: Not applicable.

Conflicts of Interest: The authors declare no conflict of interest.

\section{References}

1. Lejano, R.P.; Tan, J.M.; Wilson, A.M.W. A textual processing model of risk communication: Lessons from Typhoon Haiyan. Weather Clim. Soc. 2016, 8, 447-463. [CrossRef]

2. Tragaki, A.; Gallousi, C.; Karymbalis, E. Coastal hazard vulnerability assessment based on geomorphic, oceanographic and demographic parameters: The case of the Peloponnese (Southern Greece). Land 2018, 7, 56. [CrossRef]

3. Cutter, S.L. Living with Risk; Edward Arnold: London, UK, 1993.

4. Timmerman, P. Vulnerability Resilience and Collapse of Society. A Review of Models and Possible Climatic Applications; Institute for Environmental Studies: Toronto, ON, Canada, 1981.

5. Cardona, O.D.; van Aalst, M.K.; Birkmann, J.; Fordham, M.; McGregor, G.; Perez, R.; Pulwarty, R.S.; Schipper, E.L.F.; Sinh, B.T. Determinants of risk: Exposure and vulnerability. In Managing the Risks of Extreme Events and Disasters to Advance Climate Change Adaptation; Field, C.B., Barros, V., Stocker, T.F., Qin, D., Dokken, D.J., Ebi, K.L., Mastrandrea, M.D., Mach, K.J., Plattner, G.-K., Allen, et al., Eds.; Cambridge University Press: Cambridge, UK; pp. 65-108.

6. Long, J.; Rice, J.L. From sustainable urbanism to climate urbanism. Urban Studies 2019, 56, 992-1008. [CrossRef]

7. Walker, B.H.; Holling, C.S.; Carpenter, S.R.; Kinzig, A. Resilience, adaptability and transformability in social-ecological systems. Ecol. Soc. 2004, 9, 4. Available online: http:/ / www.ecologyandsociety.org/vol9/iss2/art5 (accessed on 1 March 2021). [CrossRef]

8. Folke, C.; Carpenter, S.R.; Walker, B.; Scheffer, M.; Chapin, T.; Rockström, J. Resilience thinking: Integrating resilience, adaptability and transformability. Ecol. Soc. 2010, 15, 20. [CrossRef]

9. Yusoff, K.; Gabrys, J. Climate change and the imagination. Wiley Interdiscip. Rev. Clim. Chang. 2011, 2, 516-534. [CrossRef]

10. Cutter, S.L.; Boruff, B.J.; Shirley, W.L. Social vulnerability to environmental hazards. Soc. Sci. Q. 2003, 84, 242-261. [CrossRef]

11. Berkes, F. Understanding uncertainty and reducing vulnerability: Lessons from resilience thinking. Nat. Hazards 2007, 41, $283-295$. [CrossRef]

12. Gidley, J.M.; Fien, J.; Smith, J.A.; Thomsen, D.C.; Smith, T.F. Participatory futures methods: Towards adaptability and resilience in climate-vulnerable communities. Environ. Policy Gov. 2009, 19, 427-440. [CrossRef]

13. Innes, J.E.; Booher, D.E. Planning with Complexity: An Introduction to Collaborative Rationality for Public Policy; Routledge: New York, NY, USA, 2018.

14. Dwyer, A.; Zoppou, C.; Nielsen, O.; Day, S.; Roberts, S. Quantifying Social Vulnerability: A Methodology for Identifying Those at Risk to Natural Hazards; Geoscience Australia Record: Canberra, Australia, 2004. 
15. Burton, C.; Cutter, S.L. Levee failures and social vulnerability in the Sacramento-San Joaquin Delta area, California. Nat. Hazards Rev. 2008, 9, 136-149. [CrossRef]

16. Linkov, I.; Bridges, T.; Creutzig, F.; Decker, J.; Fox-Lent, C.; Kröger, W.; Thiel-Clemen, T. Changing the resilience paradigm. Nat. Clim. Chang. 2014, 4, 407-409. [CrossRef]

17. Dahlberg, R. Resilience and complexity: Conjoining the discourses of two contested concepts. Cult. Unbound 2015, 7, 541-557. [CrossRef]

18. Farber, D.A. Probabilities Behaving Badly: Complexity Theory and Environmental Uncertainty; University of California: Davis, CA, USA, 2003; Volume 37, p. 145.

19. Bourdieu, P. The forms of capital. In Handbook of Theory and Research for the Sociology of Education; Richardson, J., Ed.; Greenwood Press: New York, NY, USA, 1986; pp. 241-258.

20. Stokols, D.; Lejano, R.P.; Hipp, J. Enhancing the resilience of human-environment systems: A social ecological perspective. Ecol. Soc. 2013, 18, 7. [CrossRef]

21. Emanuel, K.A. Downscaling CMIP5 climate models shows increased tropical cyclone activity over the 21st century. Proc. Natl. Acad. Sci. USA 2013, 110, 12219-12224. [CrossRef]

22. Sobel, A.H.; Camargo, S.J.; Hall, T.M.; Lee, C.Y.; Tippett, M.K.; Wing, A.A. Human influence on tropical cyclone intensity. Science 2016, 353, 242-246. [CrossRef] [PubMed]

23. Lin, N.; Emanuel, K. Grey swan tropical cyclones. Nat. Clim. Chang. 2016, 6, 106-111. [CrossRef]

24. Helgeson, J.; van der Linden, S.; Chabay, I. The role of knowledge, learning and mental models in public perceptions of climate change related risks. In Learning for Sustainability in Times of Accelerating Change; Wals, A.E.J., Corcoran, P.B., Eds.; Wageningen Academic Publishers: Wageningen, The Netherlands, 2012; pp. 329-346.

25. Van der Linden, S. The social-psychological determinants of climate change risk perceptions: Towards a comprehensive model. J. Environ. Psychol. 2015, 41, 112-124. [CrossRef]

26. Diffenbaugh, N.S. Verification of extreme event attribution: Using out-of-sample observations to assess changes in probabilities of unprecedented events. Sci. Adv. 2020, 6, eaay2368. [CrossRef]

27. Colding, J.; Gren, A.; Barthel, S. The incremental demise of urban green spaces. Land 2020, 9, 162. [CrossRef]

28. Kavanagh, M. Public Housing in the New York City: The Case of the Red Hook Houses; Fordham University: New York, NY, USA, 2013.

29. Pelling, M. Adaptation to Climate Change: From Resilience to Transformation; Routledge: New York, NY, USA, 2010.

30. Yim, W.W.S. Vulnerability and adaptation of Hong Kong to hazards under climatic change conditions. In Climate Change Vulnerability and Adaptation in Asia and the Pacific; Erda, L., Bolhofer, W.C., Huq, S., Lenhart, S., Mukherjee, S.K., Eds.; Springer: Dordrecht, The Netherlands, 1996; pp. 181-190.

31. Cox, W.; Pavletich, H. 16th Annual Demographia International Housing Affordability Survey, Rating Middle-Income Housing Affordability, Manitoba; The Frontier Centre for Public Policy: Winnipeg, Canada, 2020. Available online: http://www.demographia.com/dhi2 020.pdf (accessed on 1 March 2021).

32. Census and Statistics Department. Hong Kong Population Projections 2020-2096; HKSAR Government Printer: Hong Kong, China, 2020.

33. Kan, W.S.; Chui, E. Vouchers and consumer-directed care: Implications for community care services in Hong Kong. Br. J. Soc. Work 2021, 51, 96-113. [CrossRef]

34. Census and Statistics Department. Hong Kong Population By-Census-Main Results; HKSAR Government Printer: Hong Kong, China, 2016.

35. Chan, S.-T. Risks of storm surge \& extreme waves in Hong Kong. In Proceedings of the Annual Conference on Disaster Preparedness and Response 2019-Reduce Risks, Build Resilience, Hong Kong, China, 29 June 2019. Available online: http: / /acdpr.hkjcdpri.org.hk/pdf/ppt/3Chan_Sai_Tik.pdf (accessed on 27 February 2021).

36. Lejano, R.P.; Casas, E.V., Jr.; Pormon, M.M.M.; Yanger, M.J. Teaching to the nth: Narrative knowledge and the relational model of risk communication. Int. J. Disaster Risk Reduct. 2020, 50, 101720. [CrossRef]

37. Lejano, R.P.; Rahman, M.S.; Kabir, L. Risk Communication for empowerment: Interventions in a Rohingya refugee settlement. Risk Anal. 2020, 40, 2360-2372. [CrossRef] [PubMed]

38. Lejano, R.P.; Newbery, N.; Ciolino, M.; Newbery, D. Sustainability and incommensurability: Narrative policy analysis with application to urban ecology. Ecol. Econ. 2019, 164, 106348. [CrossRef]

39. Lejano, R.P. Climate change and the relational city. Cities 2019, 85, 25-29. [CrossRef] 